1. MBBS, FCPS (Hematology)

\title{
COMPARISON OF MEAN FERRITIN LEVEL IN PATIENTS WITH CORONARY HEART DISEASE AND CONTROL SUBJECTS.
}

Demonstrator

Department of Pathology

King Edwards Medical University \&

Hospital, Lahore.

2. MBBS, FCPS (Haematology)

Professor Haematology

Department of Pathology

Shaikh Zayed Hospital Lahore.

3. MBBS, MPhil (Hematology) Assistant Professor Hematology

Department of Pathology

Nishtar Medical University \&

Hospital, Multan.

4. MBBS, FCPS (Hematology) Assistant Professor Hematology

Department of Pathology

King Edwards Medical University \& Hospital, Lahore.

5. MBBS, FCPS (Hematology) Associate Professor Hematology Department of Pathology King Edwards Medical University \& Hospital, Lahore.

6. MBBS, MS (Cardiac Surgery) AP MO

Shaikh Zayed Hospital Lahore.

Correspondence Address:

Dr. Sindhu Rehman

Department of Pathology

King Edwards Medical University \&

Hospital, Lahore.

drsindhu.rehman@yahoo.com

Article received on:

22/10/2018

Accepted for publication:

19/03/2019

\begin{abstract}
Sindhu Rehman', Mona Aziz², Sabeen Fatima ${ }^{3}$, Sobia Ashraf ${ }^{4}$, Ambreen Hameed ${ }^{5}$, Waseem Rehman ${ }^{6}$
ABSTRACT... To determine and compare Mean ferritin level in stable diagnosed coronary heart disease and healthy control groups. Study Design: Analytic (case control study). Setting: Department of Hematology, Sheikhs Zayed Hospital, Lahore. Period: Six months (10 ${ }^{\text {th }}$ October, 2015 to $11^{\text {th }}$ April, 2016). Material \& Methods: Serum iron, total iron binding capacity (TIBC), transferrin saturation (TSAT) and serum ferritin level were measured in 75 cases with coronary heart disease $(\mathrm{CHD})$ and 75 controls (health individuals). All collected information was entered into SPSS version 20. Quantitative variables like age and serum ferritin were presented in the form of Mean \pm SD for both cases and control. Qualitative variables like gender was presented in the form of frequency and percentages. T-test was used to compare the mean serum ferritin level between cases and controls. $p \leq 0.05$ was considered statistically significant. Results: Out of 75 patients, $62(82.7 \%)$ were males and $13(17.3 \%)$ females .Serum ferritin levels were substantially raised in patient with CHD versus control subjects $\{1119 \pm 272 \mathrm{ng} / \mathrm{l}$ versus $82 \pm 139$ $\mathrm{ng} / \mathrm{l}(\mathrm{p}<.001)\}$. Total iron binding capacity $(\mathrm{TIBC})$ was lower in patient with CHD $\{274 \pm 102 \mu \mathrm{l}$ versus $355 \pm 95 \mu \mathrm{mol} / \mathrm{l}(\mathrm{p}<.000)\}$ compared to healthy subjects. Conclusion: The mean ferritin level in both groups showed statistically significant difference of serum ferritin level in patient with chronic heart disease and control group and serum ferritin level was considerably higher in patients.
\end{abstract}

Key words: $\quad$ Coronary Heart Disease, Ferritin, Iron, Total Iron-Binding Capacity, Transferrin Saturation.

Article Citation: Rehman S, Aziz M, Fatima S, Ashraf S, Hameed A, Rehman W. Comparison of mean ferritin level in patients with coronary heart disease and control subjects. Professional Med J 2019; 26(12):2048-2053.

DOI: $10.29309 / T P M J / 2019.26 .12 .251$

\section{INTRODUCTION}

Coronary heart disease is defined as " the impediment of coronary arteries most commonly by atheromatous plaque". ${ }^{1} \mathrm{CHD}$ is on the top of starring cause of expiry in many commercial countries of the world and conjointly observed a leading health diemma in underdeveloped countries. ${ }^{1}$ The world health organization estimated that by 2020 the global number of death from coronary heart disease will have risen from 7.2 million in 2002 to 11.1 million. The overall prevalence of coronary heart disease in Pakistan (2005) in adults greater than 40 years age was reported as $23 \%$ in men vs $30 \%$ in women. ${ }^{1,2}$

Known risk factors that step-up the risk for coronary heart disease are smoking, unhealthy cholesterol and lipid level, high blood pressure, diabetes mellitus and obesity. ${ }^{3}$ The build-up of plaque in coronary arteries produced coronary heart disease. A plaque build-up of Fatty material and other components on the walls of coronary arteries. This buildup causes the arteries to get constricted. As a result, blood supply to the heart can slow down or halt. It has been studied that there is possible connection of mean serum ferritin level and coronary heart disease. The reactive oxygen species are produced through the Fenton and Haber-Weiss reaction catalyzed by iron. The atheroscelorotic plaque is produced from deposition of modified LDL, as a product of lipid peroxidation at molecular level mediated by free iron radicals. Oxidized LDL so produced has been identified as a major atherogenic particle. It is present in atherosclerotic plaque, and autoantibodies against oxidized LDL 
exist in human serum, indicating presence of these particles in vivo. Oxidized LDL causes atherogenesis by many pathways, by its ability to load macrophages with cholesterol, causing chemotaxis for circulating monocytes, being cytotoxic, and by adversely altering coagulation pathways. ${ }^{4-6}$

Evidence has emerged that iron acts as a catalyst in lipid per oxidation of LDL cholesterol which is known risk factor for CHD.,8

Body iron stores are reflected by iron studies including Serum ferritin, serum iron, TIBC and Transferrin saturation. Free iron level increases in blood when stores are saturated. Normally, only a small indefinite quantity of iron lies outside these physiologic sinks. Under pathological circumtances, however, changeover of element irons, even though little in quantity liberate free radicals, produce oxidative stress due to the per oxidation of membranous organelles. Iron promoted oxidative stress may be insignificant in healthy individual, but can initiate the organ damage in some sensitive hosts. ${ }^{7,8,9}$

Increased levels of body iron stores suggest increased presence of free in in the body and increased possibility of myocardial damage. The current research is carried out to evaluate the comparison of mean ferritin level, serum iron, total iron binding capacity(TIBC) and Transferrin saturation in patients with coronary heart disease and control subjects. Serum ferritin level offers surrogate marker for total body iron overload and is directly related to amount of iron stored in body while, serum iron, TIBC are labile levels. Serum ferritin act as acute phase reactant, however this confounding variable is addressed in inclusion and exclusion criteria. This study is helpful in defining increased iron as a risk factor of CHD, evaluating the situation in our local population and adding bulk to the already existing evidence.

\section{OBJECTIVES}

The objective of this study is:

To determine and compare level of iron indices in stable diagnosed $\mathrm{CHD}$ and healthy control groups.

\section{METHODOLOGY}

The study was carried out over a duration of six months. Seventy five cases of diagnosed CHD presenting in indoor and OPD department of the Shaikh Zayed Hospital Lahore, the inclusion criteria were fullfiled as described in the study. Seventy five controls without CHD were also enrolled. Patients having chronic inflammatory/ infective disease, those on Oral /IV iron medication for more than 6 months on history and patients with recent $\mathrm{Ml}$ (i.e. history of $\mathrm{Ml}$ in 2 last weeks) were excluded.

After informed consent from cases and controls, five milliliter of fasting blood sample was collected from all subjects (including controls) to keep off from dietary effect and diurnal fluctuation on serum ferritin sample, The Serum and blood cells were separated by centrifugation within 2 hours after collection. Serum from each sample was stored in 2 sterile plastic vials containing 1.5 $\mathrm{mL}$ serum. Vials were labeled and kept frozen at $-80^{\circ} \mathrm{C}$. One for a Ferritin testing by ELISA and the other for serum Iron, TIBC. Transferrin saturation by Dimension RXL analyzer in National health science research (NHRC) laboratory, Shaikh Zayed Hospital Lahore. Mean level of serum ferritin in both cases and controls were calculated. All this information was entered to a specially designed proforma (attached).

All collected information was entered into SPSS version 20. Quantitative variables like age and serum ferritin was presented in the form of Mean \pm SD for both cases and control. Qualitative variable like gender was presented in the form of frequency and percentages. One way Anova was used to compare the mean serum ferritin level between cases and controls. $\mathrm{p} \leq 0.05$ was considered statistically significant.

\section{RESULTS}

The study was carried out over a period of six months. Seventy five patients with angiographically diagnosed CHD presenting in indoor and outdoor department of Sheikh Zayed Hospital Lahore were taken as cases (Group1).

Seventy five age and gender matched controls 
without coronary heart disease were also enrolled (Group2).

There were $62(82.7 \%)$ males and $13(17.3 \%)$ females in each group in this case control study (Figure-1).

There were more males but male to female ratio was similar in both cases and controls. Most of patients presented in sixth decade (Figure-2).

Ferritin level ranged from 19.76 to $2238 \mu \mathrm{g} / \mathrm{l}$ in cases. Mean ferritin level in cases was higher i.e. $1119.44 \pm 272.30 \mu \mathrm{g} / \mathrm{l}$ and in controls it was $82.46 \pm 139.43 \mu \mathrm{g} / \mathrm{l}(\mathrm{p}<.001)$. Serum iron level ranged from 27 to $468 \mu \mathrm{mol} / \mathrm{l}$ in cases. Mean serum iron level in cases was $61.27 \pm 57.22 \mu \mathrm{mol} / \mathrm{I}$ and in control was higher i.e. $73.21 \pm 25.66 \mu \mathrm{mol} / \mathrm{l}$ and this difference was not statistically significant. TIBC ranged from 27 to $468 \mu \mathrm{mol} / \mathrm{l}$ in cases. Mean TIBC level in cases was $274.7 \pm 102.17$ $\mu \mathrm{mol} / \mathrm{l}$ and in control was $355.40 \pm 95.04 \mu \mathrm{mol} / \mathrm{l}$ $(p<.000)$. TSAT percent was calculated from serum iron and TIBC, it ranged from 3.9 to $64 \%$ in cases, Mean TSAT in cases was $20.17 \pm 12.53 \%$ and in control was $22.46 \% \pm 22.42$ (statistically significant difference was not observed). There is significant difference between cases (Group 1) and controls (Group 2) with respect to mean TIBC and mean Ferritin as the p-value were .000 and .001 respectively. The mean value of TIBC was $274.72 \mu \mathrm{mol} / \mathrm{l}$ (lower) in cases than in controls i.e. $355.40 \mu \mathrm{mol} / \mathrm{l}$. When calculated for ferritin level, the mean value of ferritin level in cases was $1119.43 \mu \mathrm{g} / \mathrm{l}$ (higher) than in controls i.e. 82.6 $\mu \mathrm{g} / \mathrm{l}$. Hence both groups have widely different means regarding TIBC and Ferritin (Table-I).

Further analysis of case and control groups in males and females was carried out as separate groups. There was statistically significant difference ( $p$-value .006) among male cases (Group 1) and male controls (Group 2) regarding mean ferritin. Mean ferritin level in male cases was higher $(1115.5 \pm 2922.8 \mu \mathrm{g} / \mathrm{l})$ than in male controls $(71 \pm 118 \mu \mathrm{g} / \mathrm{l})$. Mean serum iron in male cases was slightly lower $(65.27 \pm 57.22 \mu \mathrm{mol} / \mathrm{l})$ than in male controls $(73.21 \pm 25.66 \mu \mathrm{mol} / \mathrm{l})$ (difference was not statistically significant). Mean TIBC level in male cases was lower i.e. $273 \pm 106.9 \mu \mathrm{mol} / \mathrm{l}$ and in male controls was $349 \pm 89.8 \mu \mathrm{mol} / \mathrm{l}$, this difference was statistically significant. TSAT was calculated and compared for male cases and controls, it was found higher in cases, but this difference was not statistically significant. Females in both groups (cases and controls) were also compared. Mean Ferritin level in female cases was $1138 \pm 1279.5 \mu \mathrm{g} / \mathrm{l}$ and in female control it was lower ie.132.2 $\pm 205 \mu \mathrm{g} / \mathrm{l}$. The $\mathrm{p}$-value was statistically significant i.e. 0.008 . Mean serum iron and TIBC level in female cases was lower than in female controls but the $p$-value was statistically significant i.e. 0.015 only for TIBC. TSAT was only slightly raised in female cases as compared to controls.

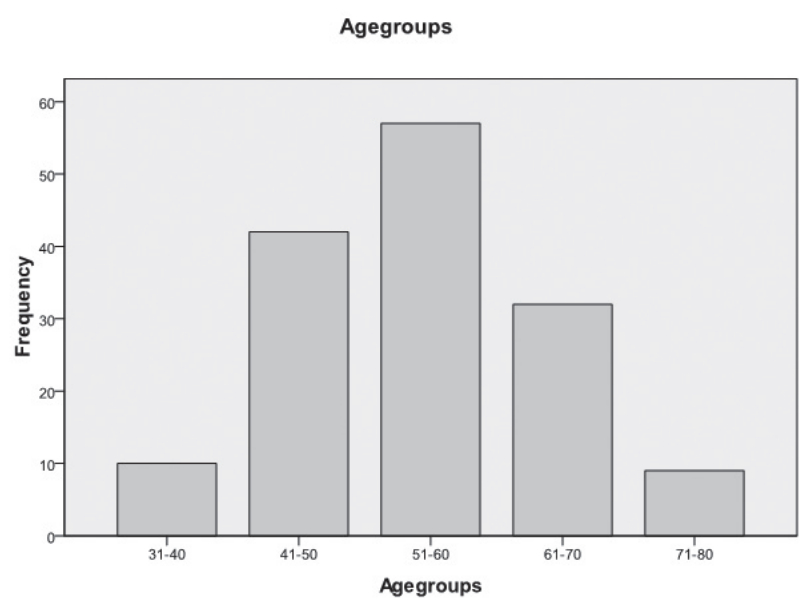

Figure-1. Age groups of cases and controls GENDER OF PATIENT

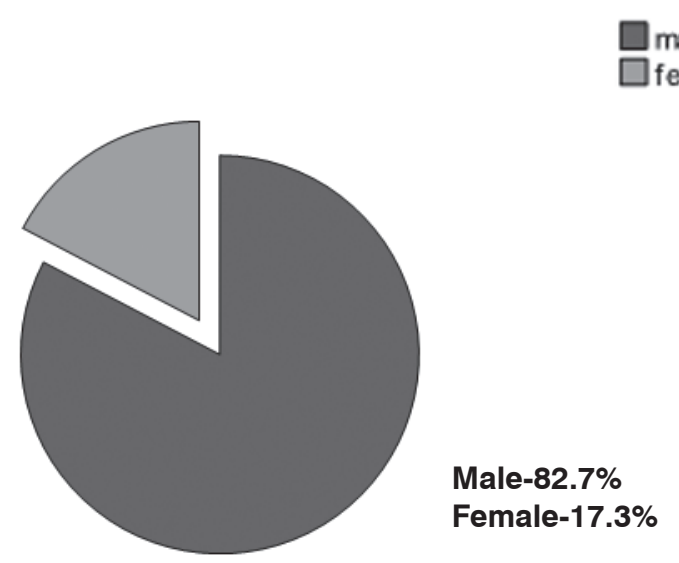

Figure-2. (Gender distribution of cases and controls) Cases $=75$ / Controls $=75$ 


\begin{tabular}{|c|c|c|c|c|c|c|c|c|}
\hline \multirow{2}{*}{$\begin{array}{c}\text { Iron Parameters } \\
\text { Group }\end{array}$} & \multicolumn{2}{|c|}{ Ferritin $(\mu \mathrm{g} / \mathrm{I})$} & \multicolumn{2}{|c|}{ S. Iron $(\mu \mathrm{mol} / \mathrm{I})$} & \multicolumn{2}{|c|}{ TIBC ( $\mu \mathrm{mol} / \mathrm{I})$} & \multicolumn{2}{|c|}{ T.SAT (\%) } \\
\hline & Group1 & Group 2 & Group1 & Group 2 & Group1 & Group 2 & Group1 & Group 2 \\
\hline $\mathrm{N}$ & 75 & 75 & 75 & 75 & 75 & 75 & 75 & 75 \\
\hline Standard deviation & 272.30 & 139.43 & 46.22 & 25.66 & 102.17 & 95.04 & 12.65 & 22.42 \\
\hline Reference range & \multicolumn{2}{|c|}{$15-300$} & \multicolumn{2}{|c|}{$10-30$} & \multicolumn{2}{|c|}{$47-70$} & \multicolumn{2}{|c|}{$155-50$} \\
\hline
\end{tabular}

\section{DISCUSSION}

Coronary heart disease is defined as "the impediment of coronary arteries most commonly by atheromatous plaque". CHD is on the top of starring cause of expiry in many commercial countries of the world and conjointly observed a leading health diemma in underdeveloped countries.

In our study, 62 males and 13 females in both case control study out of sample size 150 with mean age $57.4 \pm 9.8$ and $54.8 \pm 9.6$ respectively, there was significant difference with respect of ferritin $(p<0.006)$ and S.TIBC $(p<0.000)$ between males of both groups, and between females of both groups $(p<.008$ and $p<.015)$ respectively.

Dilek yesibersa etal observed there was significant difference between male and females with respect to ferritin value. ${ }^{10}$

Dilek yesibursa et al also observed convinced connection between plasma MDA (as a marker of oxidative stress) and ferritin level $p<0.001$. It was One of the most frequently used biomarkers, providing an indication of the lipid per oxidation level, is the plasma concentration of malondialdehyde (by product of lipid per oxidation).$^{10}$

Many studies have been carried out to asses and compare the level of serum [MDA (an oxidative stress marker)], and biochemical markers of body iron stores (serum ferritin and iron indices) in control healthy individuals, and in diagnosed cases of CHD.

The inter relation of raised iron stores and coronary heart disease was first conveyed by Sullivan to describe the gender difference in heart disease risk. The mean serum Ferritin level among the male was approximately doubled that of premenopausal female. ${ }^{11}$

Ahmed and associates also found elevated serum malondialdehyde (as marker of oxidative stress) in coronary heart disease patients. It was observed that, the mean ages of both groups was not Statistically different. ${ }^{12}$

Haidari and his group also noticed a significantly raised level of serum Ferritin in males with coronary heart disease versus normal healthy males; on the other hand they could not find a significant difference in serum Ferritin concentration when females with coronary heart disease were compared with healthy females. ${ }^{13}$

In our research the mean serum ferritin was significantly raised in patients with coronary heart disease compared with control groups i,e. $1119.44 \pm 272.30$ and $82.46 \pm 139.43(p<.001)$. Difference in TIBC was also significant. Mean TIBC level in cases was $274.7 \pm 102.17$ and in control was $355.40 \pm 95.04(p<.000)$. Difference in Serum iron level were not significant in both groups (67.55 \pm 60.90 versus $74.72 \pm 25.92$ ).

Dilek yesibursa et al found the mean serum ferritin was significantly raised in patient with coronary heart disease compared with control groups. Serum iron level were not significant in both groups and TIBC was lower in patient with coronary heart disease. ${ }^{10}$

Ahmed and associates found serum iron was significantly high in cases versus control groups. Serum Ferritin was significantly increased in coronary heart disease patients as compared to control group. whereas the levels of TIBC showed 
a significant difference in coronary heart disease patients in comparison of controls. T.SAT was showing significant increase in coronary heart disease patients as compared to control. ${ }^{12}$

Salonen et al were the first to report a significant association between serum ferritin concentrations and risk of heart attack, a component of CHD. They found that Finnish men with a serum ferritin concentration $\geq 200 \mu \mathrm{g} / \mathrm{L}$ had an $\approx 2$-fold higher risk of heart attack than did men with a concentration $<220 \mu \mathrm{g} / \mathrm{L}$. They also reported finding a significant linear association between serum ferritin and risk of heart attack. ${ }^{14}$

In our study, majority of our patients were in sixth decade. Whereas an older study reported by Aronow observed no relation of serum ferritin and new coronary events in patients aged $>62$ years. ${ }^{15}$

Stadler and colleagues utilized the less invasive procedure of electron paramagnetic resonance spectroscopy and inductively coupled plasma mass spectroscopy and (ICPMS) to measure iron in ex vivo healthy human arteries and carotid lesions. There was statistically high levels of iron in the intimae of lesions contrast with healthy controls. ${ }^{16}$

\section{CONCLUSION}

The comparison of mean ferritin level in both groups shows significant difference of serum ferritin level in patient with CHD. Serum ferritin level was significantly raised in patients with $\mathrm{CHD}$ compared versus control groups. It supports the hypothesis that the risk of CHD increases with increasing body iron stores. However, it is suggested that estimation of body iron stores by more sensitive and specific tests and further cohort studies are required to study the raised serum ferritn level on outcome of CHD.

\section{Copyright@ 19 March, 2019.}

\section{REFERENCES}

1. David A, Morras S, Bernard J, Gerish D, Braunwald E. Chronic coronary artery disease. In: Libby $\mathrm{P}$, Bonow RO, Mann DL, Zipes DP, editors. Braunwald's heart disease: a textbook of cardiovascular medicine. $8^{\text {th }}$ ed. New Delhi: Elsevier; 2008:1353-1417.
2. Jafar $\mathrm{TH}$, Jafary $\mathrm{FH}$, Jessani $\mathrm{S}$, Chaturvedi N. Heart disease epidemic in Pakistani women and men at equal risk. Am Heart J 2005; 150:221-6.

3. David A, Morras, Bernard J, Gerish, Beraunwald E. Risk factor for atherothrombotic disease. In: Peter Libby, Robert O, Bonow, Douglas L, Maun editors. Beraunwald heart heart disease $8^{\text {th }}$ ed. New Delhi: Elsevier; 2008: 939-946.

4. David A, Morras, Bernard J, Gerish, Beraunwald E. Vascular biology of atheroclerosis. In: Peter Libby, Robert O, Bonow, Douglas L, Maun editors. Beraunwald heart heart disease $8^{\text {th }}$ ed. New Delhi: Elsevier; 2008: 921-934.

5. Frank B. The iron heart hypothesis. J Am Med Assoc 2007; 297:639-41.(7)

6. Ormadegum BE, Jhon I, Adedapo ADA, Grace O. Increased serum iron associated coronary heart disease among Nigerian adult. Pak J Med Sci 2007; 23:518-22.

7. You SA, Wang Q. Ferritin in atherosclerosis. Clin Chim Acta. 2005; 357(1):1-16.

8. Andrews NC, Schmidt PJ. Iron homeostasis. Annu Rev Physiol.Pub Med J 2007; 69(69-85):69-85.

9. You SA, Wang Q. Ferritin in atherosclerosis. Clin Chim Acta. 2005; 357(1):1-16.

10. Yesilbursa D, Serdar Z, Serdar A, Dirican M, Gemici K, Ozdenir $A$, et al. The relationship of serum ferritin with malondialdehyde concentration in patient with coronary artery disease: Ferritin and oxidative stress in CAD. Internat J Angiol 2001; 10:88-91.

11. Sullivan JL, Mascitelli L. Current status of the iron hypothesis of cardiovascular disease. Pub Med $\mathrm{J}$ 2007; 98:373-7.

12. Ahmad M, Khan MA, Khan AS. Oxidative stress and level of iron indices in coronary heart disease patients. PAK JAMC 2009; 21:43-7.

13. Haidri M, Javad E, Sanati A, Hajlooi M, Ghanbilli J. Association of increased ferritin with premature coronary stenosis in men. Clin Chem 2001:1666-72.

14. Salonen JT, Nyyssonen K, Korpela H, Tuomilehto J, Seppanen R, Salonen R. High stored iron levels are associated with excess risk of myocardial infarction in eastern Finnish men. Circulation 1992; 86:803-11. 
15. Aronow WS, Ahn C. Three-year follow-up shows no association of serum ferritin levels with incidence of new coronary events in $\mathbf{5 7 7}$ persons aged $>$ or $=$ 62 years. The American journal of cardiology. 1996 Sep;78(6):678-9.
16. Stadler N, Lindner RA, Davies MJ. Direct detection and quantification of transition metal ions in human atheroscelorotic plaques: Evidence for the presence of elevated levels of iron and copper. Arterioscler Thromb Vasc Biol 2004; 24:949-54.

\begin{tabular}{|c|c|c|c|}
\hline \multicolumn{4}{|c|}{ AUTHORSHIP AND CONTRIBUTION DECLARATION } \\
\hline Sr. \# & Author(s) Full Name & Contribution to the paper & Author(s) Signature \\
\hline 1 & Sindhu Rehman & $\begin{array}{l}\text { Study design, data collecting } \\
\text { writing, the manuscript formation of } \\
\text { tables reviewed and approval. }\end{array}$ & \\
\hline 2 & Mona Aziz & $\begin{array}{l}\text { Study design, statical analysis } \\
\text { result interpretation, manuscript } \\
\text { writing and revising it critically for }\end{array}$ & \\
\hline 3 & Sabeen Fatima & $\begin{array}{l}\text { important intellectual content. } \\
\text { Data collection, formulation of } \\
\text { tables reviewed and approval }\end{array}$ & \\
\hline & & $\begin{array}{l}\text { the manuscript statical analysis, } \\
\text { interpretation of results reviewed } \\
\text { and approval the manuscript. }\end{array}$ & \\
\hline 4 & Sobia Ashraf & $\begin{array}{l}\text { Formulation of tables revised and } \\
\text { approved the manuscript. }\end{array}$ & \\
\hline 5 & Ambreen Hameed & $\begin{array}{l}\text { Formulation of tables revised and } \\
\text { approved the manuscript. }\end{array}$ & \\
\hline 6 & Waseem Rehman & $\begin{array}{l}\text { Deta collection, formulation of } \\
\text { tables and statical interpretation } \\
\text { and approval the manuscript. }\end{array}$ & 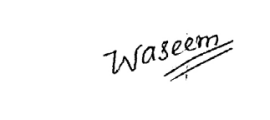 \\
\hline
\end{tabular}

